\title{
The physicochemical and sensory evaluation of commercial sour milk (amasi) products
}

\author{
Jeremia N. Moyane ${ }^{1,2 \star}$ and Afam I. O. Jideani ${ }^{1}$ \\ ${ }^{1}$ Department of Food Science and Technology, School of Agriculture, University of Venda, Private Bag X5050, \\ Thohoyandou 0950, Limpopo Province, South Africa. \\ ${ }^{2}$ Agricultural Research Council, Animal Production Institute, Gastrointestinal Tract Microbiology and Biotechnology Unit, \\ Private Bag X2, Irene, 0062 South Africa.
}

Accepted 15 March, 2013

\begin{abstract}
The physicochemical and sensory properties of five commercially available sour milk (amasi) productsAOA, AOB, AOC, AOD and AoE were analyzed in 3 batches. Samples were collected from retail shops in Thohoyandou. The products were examined for Escherichia coli, lactic acid bacteria (LAB), total plate count (TPC), pH, titratable acidity (TA), colour, viscosity and sensory properties. Microbial analysis results for $L A B$ ranged between $1.25 \times 10^{5}$ and $1.97 \times 10^{6} \mathrm{cfu}$ with sample $A O A$ and $A \circ B$ being the highest by $1.96 \times 10^{6}$ and $1.97 \times 10^{6} \mathrm{cfu}$, respectively. E. coli count ranged from $1.22 \times 10^{4}$ to $1.78 \times 10^{5} \mathrm{cfu}$ with sample AoE and AOC being the lowest and highest $(p<0.05)$, respectively. TPC had the least number of counts with the values between $4.2 \times 10^{3}$ and $9.1 \times 10^{4} \mathrm{cfu}$. The $\mathrm{pH}$ values of the products ranged between 4.22 and 4.34 and TA ranged between 0.80 and 0.84 . Colour measurements gave $L^{*}$ values of the products ranging from 33.77 to 40.19 , while $a^{*}$ and $b^{*}$ values were 3.08 to 6.43 and 13.17 to 18.77, respectively. Differences existed in viscosities of the products that were not significantly different $(p<0.05)$. Sensory score for the overall acceptability indicated that consumers did like the sour milk, as the values ranged from 3.8 to 4.4 . Although there were significant differences $(p<0.05)$ in terms of sweetness, smoothness and astringency, they did not affect the consumer acceptability of the products. Presence of $E$. coli in the sour milk products can be of health concern to consumers.
\end{abstract}

Key words: Sour milk, amasi, physicochemical, microbial.

\section{INTRODUCTION}

Traditionally, sour milk known as amasi among the Zulus in South Africa is a fermented product produced in clay pots and gourds which are used repeatedly through spontaneous fermentation of raw milk that occurs naturally at ambient temperature of $\pm 5^{\circ} \mathrm{C}$ (Bryant, 1949; Keller and Jordan 1990; Gadaga et al., 2001). Fermentation is one of the oldest methods for food preservation, which contributes to their flavor, appearance and texture (Mazahreh et al., 2008; Quasem et al., 2009). Hence fer- mented products are generally more attractive to the consumer than non-fermented ones.

However, due to the ever escalating human population size, and the advent of commercial starter cultures, commercial amasi is now produced from pasteurized milk, under controlled processing conditions. Commercially, amasi products are pasteurized before distribution and consumption, and the shelf life of the refrigerated beverages is 21 days (Beukes et al., 2001; Dlamini and Buys 
Table 1. Definition of attributes constituting the sour milk (amasi) products.

\begin{tabular}{ll}
\hline Attribute & Definition \\
\hline Sourness & Fresh sour smell, for example, fresh sour cream \\
Sweetness & Sweet sensation of sugar \\
Texture (thickness) & Resistance to flow or motion \\
Smoothness & Absence of detectable solid particles \\
Astringency & Dry feeling in the mouth, similar to mouth-feel after drinking dry red wine \\
Colour & Whiteness \\
Overall acceptability & How good is all combined attributes \\
\hline
\end{tabular}

2008; Burger, 2010). Examples of 2008; Burger, 2010). Examples of amasi products in the study location include Limpopo dairy maas, Clover Inkomazi, Save Moramasil Spar maas, Moordriftmaas and Hygienik (amaziakgomo).

Sour milk is one of the products in which microorganisms are used during its production; therefore in cases where hygienic practices are not properly applied, microbial contamination may occur during processing, distribution of product and retail outlets. The presence of Escherichia coli and coliform groups of microorganisms in sour milk could pose a potential health problem. Monitoring the quality of dairy product is important, considering the safety of the consumers. Since milk and milk products are good vehicles for both beneficial and harmful microorganisms, some of which may have health and subsequent financial consequences to the consumer, it is important to independently monitor quality. This study, therefore, examined those physical, chemical, microbial and sensory parameters that determine quality of sour milk product.

\section{MATERIALS AND METHODS}

Five commercial sour milk (amasi) products were bought from shops in Thohoyandou, Limpopo Province, South Africa. These products were coded: $\mathrm{A} \circ \mathrm{A}, \mathrm{AoB}, \mathrm{AoC}, \mathrm{AoD}$ and $\mathrm{AoE}$. The samples were refrigerated at $4^{\circ} \mathrm{C}$ at the Department of Food Science and Technology, University of Venda (Univen). The sensory evaluation, and the chemical, physical and microbial analyses were carried out in the laboratory. Titration for lactic acid concentration, $\mathrm{pH}$ determination and microbial count, colour and viscosity analysis were done.

\section{Physical analysis}

The viscosity was determined using DV-E Viscometer (Brookfield Engineering Laboratories model No. RVDVE230). Spindle no. DV-E 4 was used at a speed of $10 \mathrm{rpm}$ and the reading on the viscometer was taken after $3 \mathrm{~min}$ for each sample (Kip et al., 2006). The colour was determined as outlined in HunterLab (2008), using a Hunter Lab, ColourFlex model No. 45/0 (Hunter Associates Laboratory, Inc 11491 Sunset Hills Road, Reston, VA 20190-5280).

\section{Physicochemical analysis}

The $\mathrm{pH}$ of the samples was determined using $\mathrm{pH}$ meter, (METTLER TOLEDO, Education Line model No. EL20). The pH probe was immersed inside the $50 \mathrm{ml}$ beaker of sample. Determinations were done in triplicates. The instrument was calibrated using standard buffer solutions at $\mathrm{pH} 4$ and 7 . The lactic acid concentration was determined by weighing $10 \mathrm{~g}$ of amasi sample in a conical flask; 30 $\mathrm{mL}$ of distilled water were added to the sample and mixed well by shaking. Phenolphthalein indicator (5 drops) was added and $0.1 \mathrm{M}$ $\mathrm{NaOH}$ from the filled burette was used to titrate the solution until it retained a very slight pink tinge after mixing. The volume of $\mathrm{NaOH}$ used was recorded. Each sample was titrated three times and the percentage of lactic acid was calculated using the equation (NZIFST, 2010):

(ml of $\mathrm{NaOH}$ used) (conc NaOH) (0.090 milli equivalent weight of lactic acid) (100) $\operatorname{Acid}(\%)=\frac{\text { Weight of sample }}{\text { W }}$

\section{Enumeration of lactic acid bacteria (LAB) and E. coil}

Samples $(1 \mathrm{~mL})$ of each sour milk were serially diluted $\left(10^{-1}, 10^{-2}\right.$, $10^{-3}$ and $10^{-4}$ ) in $9 \mathrm{~mL}$ of buffered peptone water (BPW) and appropriate dilution was surface plated onto Sorbitol MacConkey agar (SMAC) (Oxoid) for E. coil and de Man Rogosa and Sharp (MRS) agar was prepared from the ingredients for Lactobacillus. MRS plates were incubated anaerobically at $37^{\circ} \mathrm{C}$ for $48 \mathrm{~h}$ for the enumeration of mesophilic lactobacilli and leuconostocs and at $42^{\circ} \mathrm{C}$ for the enumeration of thermophilic lactobacilli and streptococci, while SMAC plates were incubated aerobically for $24 \mathrm{~h}$ at $37^{\circ} \mathrm{C}$ (Dlaminiand Buys, 2008). Total viable counts were performed using plate count agar (Merck) incubated at $25^{\circ} \mathrm{C}$ for $24 \mathrm{~h}$ (Lefoka and Viljoen, 2009).

\section{Sensory analysis of sour milk products}

A panel of 10 judges familiar with the amasi from the Department of Food Science and Technology at Univen was constituted and used to evaluate the five products. The panelists were asked to score for sourness, sweetness, texture (thickness), smoothness, astringency, colour and overall acceptability of the products (Table 1) on a 5point hedonic scale ranging from 5 to 1 , where 1 is dislike very much, 3 is neither like or dislike and 5 like very much (Bille et al., 2002).

\section{Statistical analysis}

Products were analyzed in triplicates. Analysis of variance (ANOVA) was applied to the entire data set to determine the significance of the differences $(p<0.05)$ between the sour milk products using a Microsoft Excel for windows 7. 


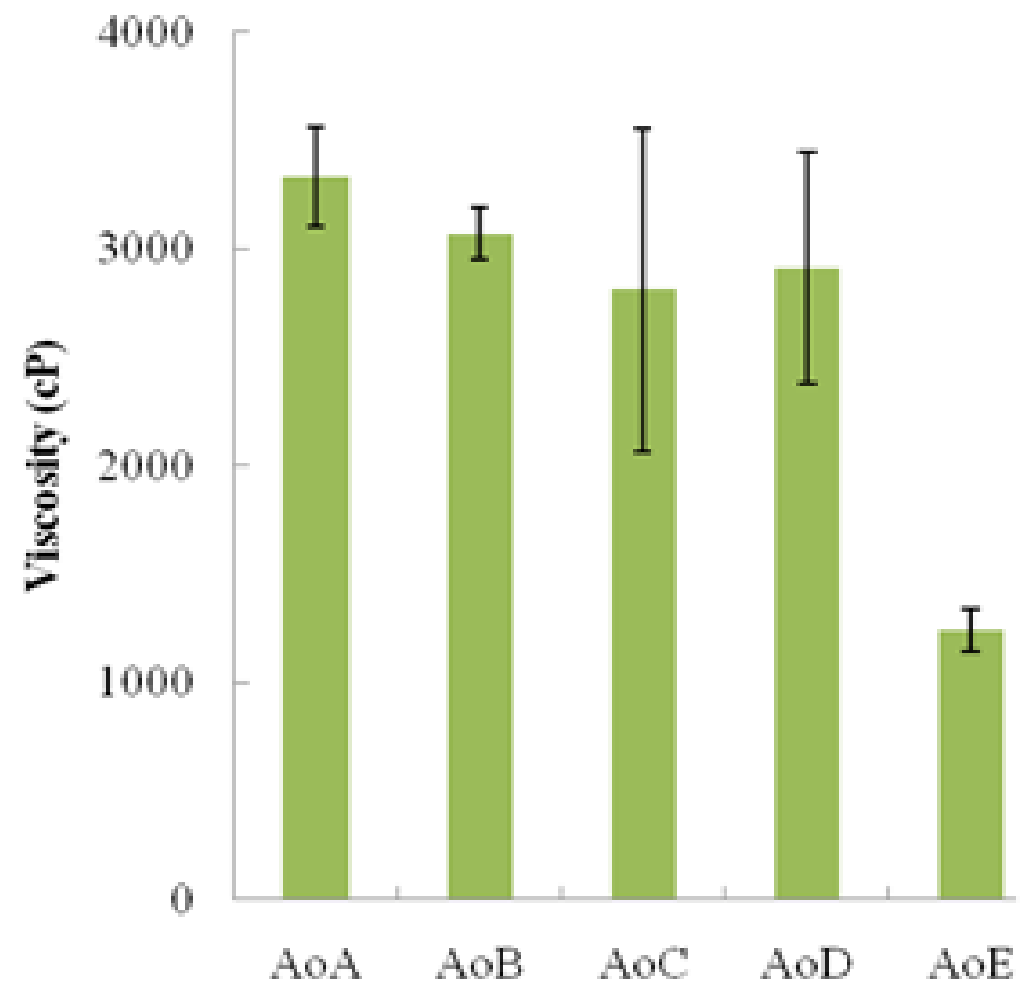

Sour milk products

Figure 1. The viscosity of commercial sour milk (amasi) products.

\section{RESULTS AND DISCUSSION}

\section{Physical analysis}

The results presented are from the following physical analysis: viscosity and colour. The results for viscosity are shown in Figure 1. It seems that sample AoA had a higher viscosity $(p<0.05)$ as compared to sample AoE which had a low viscosity. Significant differences at $p<$ 0.05 existed for the viscosity between the samples (amasi). Sample AoA showed the highest viscosity of $3330 \mathrm{cP}$, while sample AoE showed the lowest viscosity of $1240 \mathrm{cP}$ (Figure 1). There were differences $(p<0.05)$ between sample $A \circ A$ and sample $A \circ B$ and $A \circ E$, whereas there was no difference in samples $A o C$ and AoD. Sample $A o B$ differed from sample $A o C, A o D$ and $A o E$. Sample $A \circ B, A o C$ and $A o D$ had values of 3070,2810 and $2915 \mathrm{cP}$, respectively. There was no difference in viscosity between sample $A o C$ and $A o E$ but there was difference in sample AoD. More work has been done to improve the amasi using either enrichment of the milk with $2.5 \%(\mathrm{w} / \mathrm{v})$ skim milk or by dry matter ultra-filtration (Narvhus et al., 1998).

Ozerand and Atamer (1994) reported that acid development is required for fine curd formation. The study by Mustafa et al. (2001) on yoghurt recorded a viscosity value of 100 to $2825 \mathrm{cP}$. The LAB that produce exopoly- saccharides are often used to increase the viscosity of stirred fermented milks, such as yoghurt and to decrease the susceptibility to syneresis (Ruas-Madiedo et al., 2002). Sample AoE had lowest viscosity and not surprising it also recorded lowest on consumer acceptance on texture and smoothness sensory attributes.

Large curd in sample such as AoA was observed as compared to sample AoE that suggests that viscosity could have been influenced by the size of the particles and whey proteins from denaturation caused by $\mathrm{pH}$ (Masson et al., 2010). This can be caused by unavoidable variations in factors such as temperature, $\mathrm{pH}$ and mechanical vibration during production, resulting in grainy texture and varying viscosities (Anonymous, 2010).

Eissa et al. (2010) stated that prolonged metabolic activity of microflora in yogurt causes changes in the micro-structure of the media and hence affecting viscosity. This may suggest that high values on the standard deviation were caused by the length of time each set of collected samples were stored and the number of microflora of the sour milk during analysis. The viscosity is affected by the state and concentration of fats, protein, temperature, $\mathrm{pH}$ and milk age (Park, 2007).

Results for colour analysis of sour milk samples are shown in Table 2. There was no significant difference ( $p$ $<0.05)$ between the $L^{*}$ values of the sour milk samples, with all the values ranging from 34 to 40 (Table 2). The $L^{*}$ 
Table 2. The $\mathrm{pH}$ and colour parameters of commercial sour milk (amasi) products.

\begin{tabular}{|c|c|c|c|c|}
\hline \multirow{2}{*}{ Sample } & \multirow{2}{*}{ pH } & \multicolumn{3}{|c|}{ Colour } \\
\hline & & $\mathbf{L}^{*}$ & $a^{*}$ & $\mathbf{b}^{*}$ \\
\hline AoA & $4.22 \pm 0.18^{a}$ & $33.77 \pm 4.54^{\mathrm{a}}$ & $6.26 \pm 3.29^{a}$ & $16.70 \pm 1.19^{a}$ \\
\hline AoB & $4.34 \pm 0.30^{a}$ & $35.29 \pm 6.03^{a}$ & $6.43 \pm 0.08^{a b}$ & $18.77 \pm 0,71^{b}$ \\
\hline AoC & $4.23 \pm 0.12^{\mathrm{a}}$ & $38.67 \pm 0.58^{a}$ & $3.08 \pm 0.49^{a c}$ & $13.71 \pm 0.30^{\mathrm{ac}}$ \\
\hline AoD & $4.30 \pm 0.14^{a}$ & $38.04 \pm 1.84^{a}$ & $5.10 \pm 0.26^{a}$ & $16.02 \pm 0.42^{\mathrm{ad}}$ \\
\hline AoE & $4.34 \pm 0.12^{a}$ & $40.19 \pm 1.13^{a}$ & $3.78 \pm 0.31^{\mathrm{ac}}$ & $16.58 \pm 0.52^{a}$ \\
\hline
\end{tabular}

Mean values with their standard deviations. $L^{*}=$ Lightness (ranging from $0=$ black to $100=$ white); $a^{*}=$ redness and $b^{*}=$ yellowness. Values in the same column with different letters differ significantly from each other $(p<0.05)$.

indicate the black and white colour which ranges from $\mathrm{L}=$ 0 (black) to $L=100$ (white) colour, and white is the predominant colour in sour milk. Again, there was no significant difference between the $a^{*}$ values except the significant difference between sample $A \circ B$ and sample $A \circ C$ and AoE $(p<0.05)$. The $a^{*}$ values represent the redness colour intensity and were below 6 in all the samples. The $b^{*}$ values indicate the yellowness and were at high level. The yellow is one of the properties of sour milk that appears to be yellowish in colour (Burger, 2010).

The study showed that, $L^{*}$ values ranged from 34 to 40 among the three batches, confirming that the sour milk has relatively dark colour when compared with standard white colour $\left(L^{*}=100\right)$. Phillips et al. (1995) reported that $L^{*}$ value increased with the increase in fat content in milk. Whiteness in fluid milk is as a result of the presence of colloidal particles, such as milk fat globules and casein micelles, capable of scattering light in the visible spectrum (Fox and McSweeney, 1998).

Moreover the $a^{*}$ and $b^{*}$ values of sour milk were observed to be on the positive side, indicating that the product was slightly reddish yellow and the values ranged from 3.08 to 6.26 and 13.71 to 18.77 , respectively.

\section{Physicochemical analysis of amasi products}

The $\mathrm{pH}$ of the samples shown in Table 2 ranged from 4.22 to 4.34 with an average of 4.29 . Mean values in the same column with different letters differ significantly from each other $(p<0.05)$. Generally there was no significant difference between the samples in terms of $\mathrm{pH}$ values obtained (Table 2). The $\mathrm{pH}$ values of all the samples were between the range of 4.22 and 4.34 ; this is almost in the range of 3.6 and 4.2 discussed by Burger (2010). Dlamini and Buys (2008) also mentioned the $\mathrm{pH}$ of commercial amasi to be $\mathrm{pH} 4.4$.

The use of pure cultures enables different acid flavors to be developed leading to a range of fermented (cultured) products (Kurmann et al., 1992). The $\mathrm{pH}$ values obtained from the samples make amasi drinkable since the ideal values are between 4.0 and 4.5 because bitter and acid sensations are not present at this interval (da Cruz et al., 2009). The low pH in the fermented milk offers a selective environment for yeast growth, but is unfavorable for most bacteria (Fleet, 1990). However, spoilage becomes evident when the yeast population reaches $10^{5}$ to $10^{6}$ cells/g (Fleet, 1990).

The TA data are represented in Figure 2. The TA values of the sour milk samples fall within the range 0.80 and $0.84 \%$. These values were lower as compared to the TA of amasi discussed in the study by Dlamini and Buys (2008) which had the TA value of $1.4 \%$ with the $\mathrm{pH}$ of 4.0 at the initial stage. The organic acids (predominantly lactic acid) cause the $\mathrm{pH}$ of the sour milk to drop, killing the pathogenic bacteria and inhibiting the growth of many of the common spoilage micro-organisms (Gadaga et al., 2004).

\section{Lactic acid bacteria (LAB) and $E$. coil in amasi products}

The number of lactic acid bacteria (LAB) shown in Table 3 was high in all the sour milk samples (Table 3), the number of total plate count was less, while in all the sour milk samples, the number of $E$. coli ranged from $1.22 \times$ $10^{4}$ to $1.78 \times 10^{5}$. The survival of E. coli O157:H7 cells for up to several weeks in fermented dairy products, specifically cheese, sour cream, yoghurt, kefir and buttermilk, illustrates the potential health risks associated with postprocessing contamination of even low levels of this organism in various dairy foods (Dineen et al., 1998). In the study by Dlamini and Buys (2008), E. coli O157:H7 was detectable in commercial amasi after 3 days at $7^{\circ} \mathrm{C}$ but not in traditional amasi processed at ambient temperature over the same period.

The number of $L A B$ ranged between $1.25 \times 10^{5}$ and 1.97 $\times 10^{6} \mathrm{cfu} / \mathrm{mL}$ with sample $A \circ A$ and $A \circ B$ being the highest by $1.96 \times 10^{6}$ and $1.97 \times 10^{6} \mathrm{cfu} / \mathrm{mL}$, respectively. Beukes et al. (2001) reported that the lactic acid bacteria predominated the microbial population and numbers between $4.7 \times 10^{5}$ and $2.03 \times 10^{9} \mathrm{cfu} / \mathrm{mL}$ were recorded with mean of $108 \mathrm{cfu} / \mathrm{mL}$ on MRS, M17 and Rogosa agar in South African traditional fermented milks. In a study by Savadogo et al. (2004) on Fulani traditional fermented milk in Burkina Faso, they obtained almost similar results where the mean count of thermophilic bacteria $\left(42^{\circ} \mathrm{C}\right)$ on MRS agar, $8.04 \times 10^{5} \mathrm{cfu} / \mathrm{mL}$ was less than the mean mesophilic count $\left(35^{\circ} \mathrm{C}\right), 7.80 \times 10^{7} \mathrm{cfu} / \mathrm{mL}$ indicating the predominance 


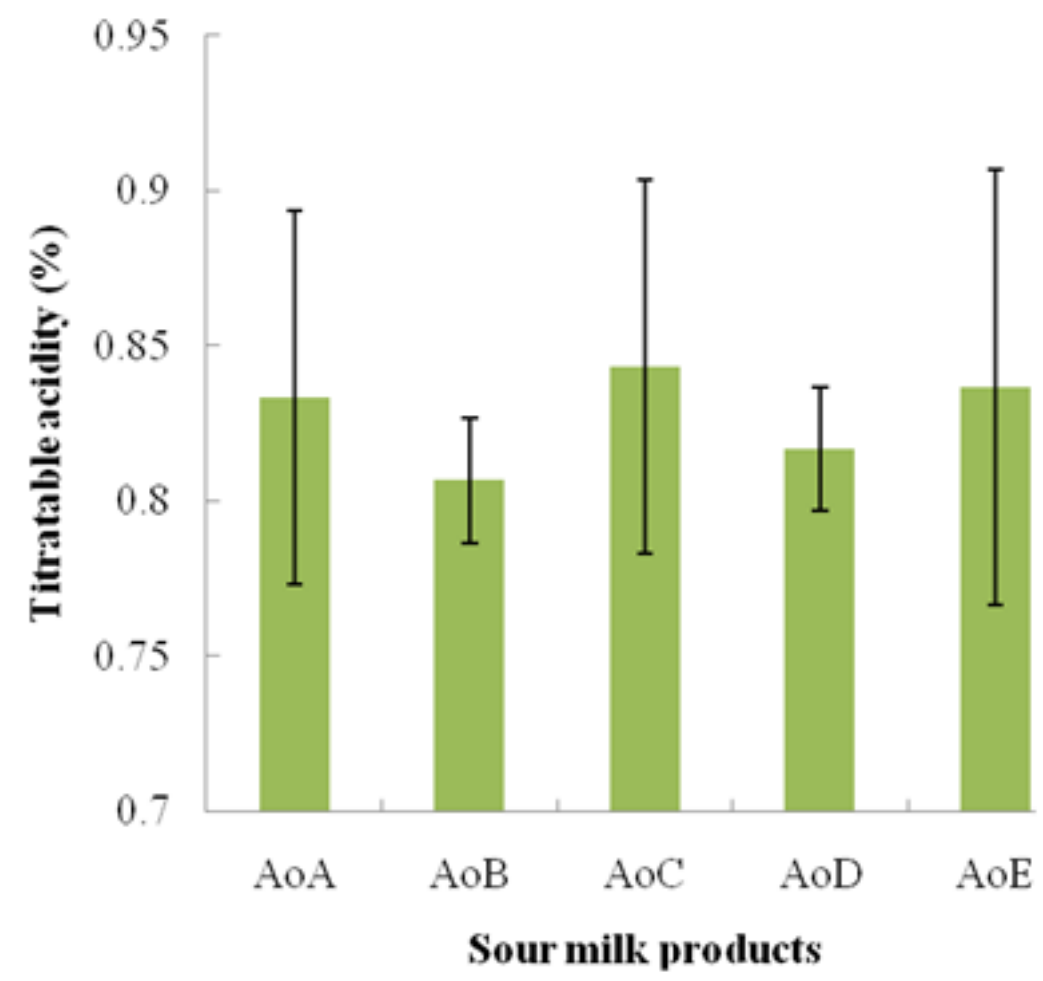

Figure 2. Titratable acidity (TA) of commercial sour milk (amasi) products.

Table 3. Microbial count of commercial sour milk (amasi) products.

\begin{tabular}{lccc}
\hline Samples & LAB (cf $/ \mathrm{mL})$ & E. coli $(\mathbf{c f} / \mathrm{mL})$ & Total plate count $(\mathbf{c f} / \mathrm{mL})$ \\
\hline AoA & $1.03 \times 10^{6} \pm 0.98$ & $7.80 \times 10^{4} \pm 0.09$ & $4.20 \times 10^{3} \pm 2.40$ \\
AoB & $1.97 \times 10^{6} \pm 1.19$ & $7.20 \times 10^{4} \pm 1.10$ & $9.09 \times 10^{4} \pm 0.80$ \\
AoC & $1.80 \times 10^{6} \pm 0.74$ & $1.78 \times 10^{5} \pm 1.02$ & $8.20 \times 10^{3} \pm 0.90$ \\
AoD & $4.81 \times 10^{5} \pm 3.94$ & $2.09 \times 10^{4} \pm 0.41$ & $2.66 \times 10^{4} \pm 0.44$ \\
AoE & $1.27 \times 10^{6} \pm 0.09$ & $1.22 \times 10^{4} \pm 1.28$ & $7.55 \times 10^{4} \pm 1.75$ \\
\hline
\end{tabular}

$\mathrm{LAB}=$ lactic acid bacteria.

of lactic acid bacteria. The mean count of coliforms was $0.98 \times 10^{4} \mathrm{cfu} / \mathrm{mL}$ for 25 samples. Dlamini and Buys (2008) also found that $L A B$ counts in commercial amasi inoculated with $A A$ and NA E. coli O157:H7 increased from 7.0 to $8.1 \log _{10} \mathrm{cfu} / \mathrm{mL}$. Differences in experimental conditions such as different fermentation temperatures and storage could have caused this difference.

High viable counts of $L A B$ are necessary to get the desired acid production, which affects the product shelflife (Helland et al., 2004). LAB also plays a major role in the development of flavour and aroma through the production of flavouring compounds such as diacetyl, acetoin and acetyaldehyde (Oberman and Libudzisz, 1998).

\section{Consumer acceptability of amasi products}

The mean scores for sensory properties of the sour milk samples are shown in Table 4. Five samples were evaluated for sourness, sweetness, texture, astringency, colour and overall acceptability. There were no significant differences observed between the samples in terms of texture, colour and overall acceptability (Table 4). However, there were some significant differences in sweetness, smoothness and astringency properties of the samples. Sample AoA was the most liked by the consumers than sample AoE. Sensory properties of foods offer quality control criteria.

The sensory score indicate that consumers did like the sour milk, as the overall acceptability ranges from 3.8 to 4.4 where 5 is like very much, and 1 being dislike very much (Table 4). The annual consumption of amasi is considerable in South Africa and an estimated 104 million liters were consumed in 2003 by black miners alone (McMaster et al., 2005). In this study, the most liked 
Table 4. Sensory properties of commercial sour milk (amasi) products.

\begin{tabular}{lccccccc}
\hline \multirow{2}{*}{ Sample } & \multicolumn{7}{c}{ Sensory attributes } \\
\cline { 2 - 7 } & Sourness & Sweetness & Texture & Smoothness & Astringency & Colour & Overall acceptability \\
\hline $\mathrm{AoA}$ & $4.5 \pm 0.97^{\mathrm{a}}$ & $3.8 \pm 1.23^{\mathrm{ac}}$ & $4.0 \pm 0.94^{\mathrm{a}}$ & $4.3 \pm 1.06^{\mathrm{a}}$ & $4.3 \pm 1.06^{\mathrm{a}}$ & $4.4 \pm 0.97^{\mathrm{a}}$ & $4.4 \pm 0.70^{\mathrm{a}}$ \\
$\mathrm{A} \mathrm{B}$ & $3.7 \pm 0.95^{\mathrm{a}}$ & $3.1 \pm 0.57^{\mathrm{a}}$ & $3.8 \pm 1.03^{\mathrm{a}}$ & $3.7 \pm 1.34^{\mathrm{ab}}$ & $3.6 \pm 1.51^{\mathrm{ab}}$ & $4.2 \pm 1.03^{\mathrm{a}}$ & $4.0 \pm 0.67^{\mathrm{a}}$ \\
$\mathrm{A} \mathrm{C}$ & $3.7 \pm 1.25^{\mathrm{a}}$ & $2.7 \pm 0.67^{\mathrm{b}}$ & $3.8 \pm 0.79^{\mathrm{a}}$ & $3.6 \pm 1.07^{\mathrm{b}}$ & $4.0 \pm 1.05^{\mathrm{b}}$ & $4.3 \pm 0.67^{\mathrm{a}}$ & $3.8 \pm 0.92^{\mathrm{a}}$ \\
$\mathrm{A} \mathrm{D}$ & $3.7 \pm 1.34^{\mathrm{a}}$ & $4.0 \pm 1.25^{\mathrm{c}}$ & $3.9 \pm 0.74^{\mathrm{a}}$ & $4.3 \pm 0.48^{\mathrm{a}}$ & $3.8 \pm 1.03^{\mathrm{a}}$ & $4.5 \pm 0.71^{\mathrm{a}}$ & $4.3 \pm 0.67^{\mathrm{a}}$ \\
$\mathrm{A} \mathrm{E}$ & $3.3 \pm 1.25^{\mathrm{b}}$ & $3.3 \pm 0.95^{\mathrm{ad}}$ & $3.6 \pm 1.07^{\mathrm{a}}$ & $3.2 \pm 0.79^{\mathrm{bc}}$ & $3.1 \pm 1.29^{\mathrm{c}}$ & $4.0 \pm 0.82^{\mathrm{a}}$ & $3.8 \pm 1.14^{\mathrm{a}}$ \\
\hline
\end{tabular}

Sensory characteristics were graded on the scale $1=$ dislike very much; $5=$ like very much. Mean values in the same column with different letters differ significantly from each other $(p<0.05)$.

sensory attribute was the colour with the scores between 4.0 and 4.5. The analysis of the aroma of dairy products is complex due the heterogonous nature of milk.

Sample astringency increased with storage time (Irigoyen et al., 2005). In contrast, Katsiari et al. (2002) found that storage did not significantly affect the sensory attributes of yoghurt samples. This can be true because the sour milk products examined in this study had different expiring dates. Moreover, their astringency was not affected by the storage period as the panelists did not judge the products based on the influence of storage period. However, significant differences existed between the examined sour milk products.

\section{Conclusion}

The outcome of this study showed the availability of $E$. coli in the sour milk products which can be of health concern to consumers. Lactic acid bacteria dominated the count in all the products in MRS media and the total plate count showed low bacteria count. However, the significant differences which existed on other parameters tasted did not affect the consumer acceptability as it was predicted.

\section{REFERENCES}

Anonymous (2010). LabPlusInternational. Technology to achieve smooth fermented milkproducts [wwwDodument] http://www.labintonline.com/index.php?id=1031andtx_ttproducts_pi1[ product $=1593$ Accessed 10-02-2011

Beukes EM, Bester BH, Mostert JF (2001). The microbiology of South African traditional fermented milks. Int. J. Food Microbiol. 63:189197.

Bille PG, Ozuuko ATR, Ngwira T (2002). Sensory properties of traditionally-fermented buttermilk (Omashikwa) processed in Namibia. J. Food Tech. Afr. 7(2):52-54.

Bryant AT (1949). The Zulu People as they were before the White Man Came. $1^{\text {st }}$ edition.Shuter and Shooter, Pietermaritzburg, South Africa, pp. 270-271.

Burger L (2010). Amasi's sweet success - August, [www document] URL

http://www.dairyconnect.co.za/dairyMail/issues/aug2010/amazis_swe et success.djhtml Accessed 07-10-2010.

da Cruz AG, Walter EHM, Cadena RS, Faria JAF, Bolini HMA, Frattini Fileti AM (2009). Monitoring the authenticity of low-fat yogurts by an artificial neural network. J. Dairy Sci. 92(10):4797-4804.
Dineen SS, Takeuchi K, Soudah JE, Boor KJ (1998). Persistance of Escherichia coli O157:H7 in dairy fermentation systems. J. Food Prot. 61:1602-1608.

Dlamini BC, Buys EM (2008). Adaptation of Escherichia coli 0157:H7 to acid in traditional and commercial goat milk amasi. J. Food Microbiol. 26(1):58-64.

Eissa EA, Mohamed Ahmed IA, Yagoub AEA, Babiker EE (2010). Physicochemical, microbiological and sensory characteristics of yoghurt produced from goat milk. Livestock Research for Rural Development.Volume 22, Article \#137. [WWW Document]http://www.Irrd.org//rrd22/8/eiss22137.htmAccessed 2302-2011

Fleet GH (1990). Yeasts in dairy products. J. Appl. Bacteriol. 68:199211.

Fox PF, McSweeney PLH (1998). Physical properties of milk. In: Dairy chemistry and biochemistry. Fox PF, McSweeney PLH (eds.), London: Blackie Academic and Professional. pp. 437-462.

Gadaga TH, Mutukumira AN, Narvhus JA (2001). Growth characteristics of Candida kefyr and two strains of Lactococcus lactis subsp. lactis isolated from Zimbabwean naturally fermented milk. Int. J. Food Microbiol. 70(1-2):11-19.

GadagaTH, Nyanga LK, Mutukumira AN (2004). The occurrence, growth and control of pathogens in African fermented foods. Afr. J. Food Agric. Nutr. Dev. 4(1):20-23.

Helland MH, Wicklund T, Narvhus JA (2004). Growth and metabolism of selectes strains of probiotic bacteria, in maise porridge with added malted barley.Intern. J. Food Microbiol. 91:305-313.

Irigoyen A, Arana I, Castiella M, Torre P, Ibáñez FC (2005). Microbiological, physicochemical, and sensory characteristics of kefir during storage. Food Chem. 90:613-620.

Katsiari MC, Voutsinas LP, Kondyli E (2002). Manufacture of yogurt from stored frozen sheep's milk. Food Chem. 77:413-420.

Keller JJ, Jordan I (1990). Fermented milks for the South African market.S.Afric. J. Dairy Sci. 22:47-49.

Kip P, Meyer D, Jellema RH (2006). Inulins improve sensoric and textural properties of low-fat yoghurts. Int. Dairy Sci. 16:1098-1103.

Kurmann JA, Rasic JL, Kroger M (1992). Encyclopedia of fermented fresh milk products. An international inventory of fermented milk, cream, buttermilk, whey, and related products. Van Nostrand Reinhold. ISBN 0-442- 00869-4 New York. USA.

Lefoka M, Viljoen BC (2009). The survival of microbial pathogens in dairy products. Master's thesis in Faculty of Natural and Agricultural Sciences, Department of Microbial, Biochemical and Food Biotechnology, University of the Free State, Bloemfontein, South Africa.

Masson LMP, Calado VMA, Deliza R, Rosenthal A (2010). Rheological behavior of fermented dairy beverages obtained from the ultra-high pressure homogenization (UHPH), International Conference on Food Innovation.Food Innova.Dijon, France.

Mazahreh AS, AI-Shawabkeh AF, Quasem JM (2008). Evaluation of the chemical and sensory attributes of solar and freeze-dried jameed produced from cow and sheep milk with the addition of carrageenan mix to the Jameed paste. Am. J. Agric. Biosci. 3(3):627-632.

McMaster LD, Kokott SA, Reid SJ, Abratt VR (2005). Use of traditional African fermented beverages as delivery vehicles for 
Bifidobacterium lactis DSM 10140. Int. J. Food Microbiol. 102:231237.

Mustafa G, Ahmet E, Huseyin T, Selahattin S (2001). Some quality criteria of yogurt made from added with antibiotic at different levels. Pak. J. BioSci. 4(7):886-887.

Narvhus JA, Østeraas K, Mutukumira T, Abrahamsen RK (1998). Production of fermented milk using a malty compound producing strain of Lactococcus lactis subsp.lactisbiovar.diacetylactis isolated from Zimbabwean naturally fermented milk. Int. J. Food Microbiol. 41:73-80.

NZIFST (2010). New Zealand Institute of Food Science and Technology. Food Science Experiments [www document] URL http://www.nzifst.org.nz/myfiles/Expt_5._Sour_Cream_Chemistry_g uide.doc Accessed 10-05-2010

Oberman H, Libudzisz Z (1998). Fermented milks. In: Microbiology of fermented foods. 2nd Ed. Wood BJB (Ed.), Blackie Academic and Professional.Thompson Science, 2-6 Boundary Row, London, UK. pp. 319-321.

Ozer HS, Atamer M (1994). Gida.19: 155-160. (As cited by) Mustafa G, Ahmet E, Huseyin T, Selahattin S, (2001). Some quality criteria of yogurt made from added with antibiotic at different levels. Pak. J. Biosci. 4(7):886-887.
Park YW (2007). Rheological characteristics of goat and sheep milk. Small Rumin. Res. 68(1-2):73-87.

Phillips LG, McGrift ML, Barbano DM, Lawless HA (1995).The influence of fat on the sensory properties, viscosity and colour of low fat milk. J. Dairy Sci. 78:1258-1266.

Quasem JM, Mazahreh AM, Afaneh IA, Omari A (2009). Solubility of solar dried Jameed. Pak. J. Nutr. 8(2):134-138.

Ruas-Madiedo P, Tuinier R, Kanning M, Zoon P (2002). Role of exopolysaccharides produced by Lactococcus lactis subsp. cremoris on the viscosity of fermented milks. Int. Dairy J. 12:689-695.

Savadogo A, Ouattara CAT, Savadogo PW, Ouattara AS, Barro N Traore AS (2004). Microorganisms Involved in Fulani traditional fermented milk in Burkina Faso. Pak. J. Nutr. 3(2):134-139. 